\section{Proline content and yield com- ponents of local corn cultivars from Kisar Island, Maluku, Indonesia}

\author{
Hermalina Sinay, ${ }^{1,2}$ Estri Laras \\ Arumingtyas, ${ }^{1}$ Nunung Harijati, ${ }^{1}$ \\ Serafinah Indriyani ${ }^{1}$ \\ 'Department of Biology, Faculty of \\ Mathematics and Natural Sciences, \\ Brawijaya University, Malang; ${ }^{2}$ Biology \\ Education Programe, Faculty of Teaching \\ and Education, Pattimura University, \\ Ambon, Indonesia
}

\section{Abstract}

Proline is one of amino acid that usually accumulates inside the plant cell when facing drought stress. The accumulation of proline can protect the plant cell from damage during drought. The aim of this research was to determine proline content and yield components of local corn cultivars from Kisar Island, Maluku, Indonesia. The field trial was organized using randomized block design with three replicates. Six local corn cultivars found in Kisar Island (Deep Yellow, Early Maturing Yellow, Red Blood, Rubby Brown Cob, Waxy, and White) were used as plant materials and a recommended tolerance variety (Srikandi) was taken as reference group. Proline content was determined using ninhydrin method. Yield components variables included cob weight (at harvest, after air dry, after oven dried, at $12 \%$ of water content), cob water content at harvest, cob length, cob diameter, number of seed row per cob, number of seed per cob, and cob yield at $12 \%$ of water content. Data collected was analysed with analysis of variance followed by Duncan multiple range test at the significant level 0.05 using Statistical Analysis System/SAS software version 9.0. The result shows that highest proline content and yield components (except for cob water content) was showed by the Deep Yellow cultivar. The lowest proline content was showed by Rubby Brown Cob cultivar. The lowest corn yield components was showed by Red Blood local cultivar. Deep Yellow cultivar can be proposed as superior drought tolerance variety, and can be recommended for further wide cultivation in Maluku province.

\section{Introduction}

About $41 \%$ of Earth's land surface is covered by dryland. ${ }^{1}$ In Indonesia, as much as $40 \%$ of agricultural land is dryland. ${ }^{2}$ Kisar Island is part of Southwest Maluku district in Maluku province that known as dry area with dry climates and very low rainfall (991-1102 $\mathrm{mm} /$ year, or 19.05-21.19 $\mathrm{mm} /$ week). ${ }^{3}$ In Maluku, this area also known as a major contributing area of corn. However, one of the problem associated with dryland and very low rainfall in this area is the low productivity of corn (1.0 t/ha with harvest area 16,460 ha). ${ }^{4-6}$

When experiencing to dryland or drought environment conditions, plant have a special mechanism to overcome the drought stress like synthesis of osmolyte. ${ }^{7}$ The synthesis and accumulation of osmolyte can protect plant cells from damage caused by drought stress. ${ }^{8}$ One of the osmolyte that accumulate in the plant cell during drought is proline. ${ }^{9,10}$ The increasing of proline accumulation during drought stress in various plant species have been reported by many researcher such as on peanut, ${ }^{11}$ soybean, ${ }^{12}$ and patchouli. ${ }^{13}$ In corn, proline accumulation due to drought have been reported at the germination stage, ${ }^{14}$ vegetative stage, ${ }^{15}$ and reproductive stage. ${ }^{7,16-18}$ Drought stress can also significantly affect plant production including corn. ${ }^{18-20}$

Information regarding the potential yield and adaptability of the plants through the synthesis and accumulation of osmolyte is the most important factors that should be understandable by researcher or a breeder in order to obtain the best and stable genotype which can be used in a wider cultivation. This is caused by the phenotypic expression of a genotype can be changed in accordance with the ability to adapt to environmental conditions. In Kisar Island Southwest Maluku district, there are six local corn cultivars that have been cultivated by local people for a long time since many years. However, the potential yield and adaptability through proline synthesize and accumulation of six local cultivars has not been studied. The aim of this research was to determine the proline content and yield components, and wich one of these local corn cultivars that can be recommended for wider cultivation based on the proline content and yield components.

\section{Materials and Methods}

The plant materials consist of six local corn cultivars obtained from farmers in Kisar Island (Deep Yellow, Early Maturing Yellow, Red Blood, Rubby Brown, Waxy, and White) and one reference variety (Srikandi) from Research Institute for Cereals. The experiment was conducted in Yawuru District Kisar Island, South West Maluku Regency from December 2013 to March 2014, using random-
Correspondence: Hermalina Sinay, Department of Biology, Faculty of Mathematics and Natura Science, Brawijaya University, Jalan Veteran Malang 65145, East Java, Indonesia.

Tel.:+62.0341.575841-Fax: +62.0341.575841

E-mail: herlinbio@yahoo.co.id

Key words: Proline; yield components; corn.

Acknowledgments: this research was a part of first author doctoral research project wich was funded by the Directorate of Higher Education Ministry of Research Technology and Higher Education The Republic of Indonesia. The authors greatly ackowledge for the availability of these funding.

Contributions: HS, performed most of experimental work, data collecting and analyzing, manuscript writing; ELA, NH, SI, supervised experimental work, helped correct the paper, perpormed the english language of the paper.

Conflict of interest: the authors declare no conflict of interest.

Conference presentation: part of this paper was presented at the International Biological Science Conference, 2014 Sept 29-30, Faculty of Science, Prince of Songkhla University, Phuket, Thailand

Received for publication: 9 June 2015 .

Revision received: 12 August 2015.

Accepted for publication: 12 August 2015.

This work is licensed under a Creative Commons Attribution-NonCommercial 3.0 International License (CC BY-NC 3.0).

(C) Copyright H. Sinay et al., 2015

Licensee PAGEPress srl, Italy

International Journal of Plant Biology 2015; 6:6071 doi:10.4081/pb.2015.6071

ized block design with three replicates. The environmental condition were measured including temperature wich is ranging from $27.1^{\circ} \mathrm{C}$ (Dec 2013) and $28.5-28.9^{\circ} \mathrm{C}$ (JanuaryMarch 2014). The rainfall was about 47.84 $\mathrm{mm} /$ week (Dec 2013), and 17-3-0.2 mm/week (January-March 2014)

Plots size was $1.5 \times 1.5 \mathrm{~m}$. One plot with nine planting holes planted with four seeds per hole and thinned at thirty days after planting. There was $50 \times 50 \mathrm{~cm}$ space between each planting hole in each plot. There was no fertilizer and watering applied during planting season. Observation were carried out on 1 purposed selected plants leaves at 65 days after planting using the second leaf from tip for proline analysis, while yield components analysis were conducted after harvesting from 3 selected plants.

Proline analysis was conducted following the nynhidrin method. ${ }^{21}$ Fresh leaves with the weight of $0.25 \mathrm{~g},{ }^{17}$ was milled in mortar and 
pestle, and homogenized with $10 \mathrm{~mL}$ of $3 \%$ sulphosalysilic acid (w/v). The homogenate then centrifugated at $6000 \mathrm{rpm}$ for 15 minutes. The supernatant obtained was poured in-to new test tube and filtered using Whatman filter paper number 40 . Two mililiters of supernatant was taken and added with $2 \mathrm{~mL}$ of glacial acetic acid and $2 \mathrm{~mL}$ of acid nynhidrin. The acid nynhidrin wich is consist of $60 \mathrm{~mL}$ of 2.5 grams nynhidrin in $100 \mathrm{~mL}$ of glacial acetic acid, $30 \mathrm{~mL}$ of aquadest and $10 \mathrm{~mL}$ of $85 \%$ phosphoric acid was prepared following the methods of Clausen. ${ }^{22}$

The solution then heated at $100^{\circ} \mathrm{C}$ of boiling water for one hour, and incubated on ice for 5 minutes. The solution then extracted with 4 $\mathrm{mL}$ of toluene, and vortex vigorously for $10 \mathrm{sec}-$ ond. The upper phase of solution was taken, and the absorbance was measured at $520 \mathrm{~nm}$ of wavelength by using UV-VIS Spectrophotometer. For the standart curve, series of proline concentration $(2.5-20 \mu \mathrm{g} / \mathrm{mL})$ was made using pure DL-prolin (Merck; Kenilworth, NJ, USA). Proline concentration then calculated and expressed as $\mu$ mole/g fresh weight. The observation of corn yield was conducted when the husk turned to yellow or brownish. ${ }^{23}$ The yield components observed were cob weight at harvest, cob weight after air dry, cob weight after oven dried, cob water content after air dry, cob weight at $12 \%$ of water content, cob length, cob diameter, number of seed row per cob, number of seed per cob, and cob yield at $12 \%$ of water content. Data then analysed using analysis of variance followed with Duncan multiple range test at the significant level of 0.05 . Anova and Duncan was conducted with the assistance of statistical analytical system (SAS) version of 9.0 .

\section{Results and Discussion}

Table 1. Proline content and yield components of corn from Kisar Island Maluku (Indonesia).

\begin{tabular}{|c|c|c|c|c|c|c|c|}
\hline Variable tested & \multicolumn{5}{|c|}{ Corn cultivars } & White & Srikandi \\
\hline Proline content ( $\mu$ mole/gFW) & $13.8 \pm 3.1^{\mathrm{b}}$ & $17.0 \pm 4.6^{\mathrm{b}}$ & $17.3 \pm 2.9^{b}$ & $18.4 \pm 1.4^{\mathrm{b}}$ & $27.4 \pm 4.6^{\mathrm{a}}$ & $14.2 \pm 2.9^{b}$ & $18.7 \pm 2.5^{b}$ \\
\hline Cob weight when harvest (g) & $73.4 \pm 4.7^{b}$ & $46.7 \pm 3.7^{c}$ & $67.1 \pm 9.0^{\mathrm{bc}}$ & $85.6 \pm 6.7^{b}$ & $128.0 \pm 24.0^{\mathrm{a}}$ & $88.3 \pm 7.3^{b}$ & $69.6 \pm 14.7^{b}$ \\
\hline Cob weight after air dry (g) & $70.3 \pm 4.7^{\mathrm{b}}$ & $44.5 \pm 4.9^{c}$ & $64.1 \pm 7.6^{\mathrm{bc}}$ & $80.7 \pm 6.4^{b}$ & $122.5 \pm 23.2^{\mathrm{a}}$ & $85.5 \pm 7.2^{\mathrm{b}}$ & $66.5 \pm 18.6^{\mathrm{bc}}$ \\
\hline Cob weight after oven dried (g) & $59.5 \pm 4.1^{\mathrm{b}}$ & $38.15 \pm 3.34^{c}$ & $50.9 \pm 8.6^{\mathrm{bc}}$ & $68.6 \pm 5.1^{\mathrm{b}}$ & $104.1 \pm 20.5^{\mathrm{a}}$ & $70.9 \pm 4.9^{b}$ & $56.0 \pm 11.8^{\mathrm{bc}}$ \\
\hline Cob water content when harvest (\%) & $19.4 \pm 0.4^{\mathrm{a}}$ & $19.4 \pm 0.7^{\mathrm{a}}$ & $19.4 \pm 0.8^{\mathrm{a}}$ & $19.7 \pm 0.2^{\mathrm{a}}$ & $19.5 \pm 0.8^{\mathrm{a}}$ & $19.6 \pm 1.1^{\mathrm{a}}$ & $19.4 \pm 0.8^{\mathrm{a}}$ \\
\hline Cob weight at the $12 \%$ of water content $(\mathrm{g})$ & $67.3 \pm 4.6^{\mathrm{b}}$ & $42.6 \pm 3.6^{\mathrm{c}}$ & $61.4 \pm 8.2^{\mathrm{bc}}$ & $77.4 \pm 6.2^{b}$ & $117.0 \pm 21.6^{\mathrm{a}}$ & $80.6 \pm 5.6^{\mathrm{b}}$ & $62.3 \pm 16.4^{\mathrm{bc}}$ \\
\hline Cob yield at the $12 \%$ of water content (ton/ha) & $0.3 \pm 0.02^{b}$ & $0.1 \pm 0.02^{\mathrm{c}}$ & $0.2 \pm 0.04^{b}$ & $0.3 \pm 0.02^{b}$ & $0.5 \pm 0.09^{\mathrm{a}}$ & $0.3 \pm 0.03^{b}$ & $0.2 \pm 0.06^{b}$ \\
\hline Cob length (mm) & $86.8 \pm 0.8^{\mathrm{cd}}$ & $73.4 \pm 1.05^{\mathrm{d}}$ & $94.3 \pm 8.5^{\mathrm{bc}}$ & $110.02 \pm 2.8^{\mathrm{ab}}$ & $116.1 \pm 2.6^{\mathrm{a}}$ & $103.6 \pm 10.9 \mathrm{abc}$ & $98.7 \pm 8.8^{a b c}$ \\
\hline Cob diameter (mm) & $31.00 \pm 4.1^{\mathrm{c}}$ & $30.1 \pm 1.8^{c}$ & $31.7 \pm 1.1^{\mathrm{bc}}$ & $34.8 \pm 3.2^{b}$ & $38.0 \pm 1.8^{\mathrm{a}}$ & $35.4 \pm 0.6^{\text {ab }}$ & $33.2 \pm 1.1^{\mathrm{bc}}$ \\
\hline Number of seed per cob (seed) & $242.3 \pm 44.7^{\mathrm{b}}$ & $185.5 \pm 16.2^{b}$ & $205.0 \pm 16.3^{b}$ & $243.5 \pm 50.2^{b}$ & $341.5 \pm 37.6^{\mathrm{a}}$ & $247.6 \pm 23.7^{b}$ & $203.4 \pm 46.7^{\mathrm{b}}$ \\
\hline Number of seed row per cob (row) & $10.8 \pm 0.1^{\mathrm{b}}$ & $10.6 \pm 0.8^{b}$ & $11.1 \pm 0.5^{b}$ & $10.3 \pm 0.5^{b}$ & $14.1 \pm 0.6^{\mathrm{a}}$ & $11.6 \pm 0.3^{b}$ & $10.7 \pm 1.0^{b}$ \\
\hline
\end{tabular}

Number followed with same letters in the same rows means no significant different at $\alpha 0.05$ according to DMRT.

The highest value of proline content was showed by Deep Yellow local cultivar and the lowest proline content was showed by Rubby Brown Cob local cultivar (Table 1). Proline is an organic compound that most accumulated in plant when experience to drought stress. ${ }^{24}$ The function of proline in the plant cell was to keep the stability or turgidity of the cell, and protect the cell from damage due to drought. ${ }^{24}$ With the accumulation of proline inside the plant cell, it is expected to give a positive effect to the physiological process wich lead to the increase of plant yield.

The highest value of cob weight at harvest was showed by Deep Yellow cultivar, and the lowest one in the Red Blood cultivar (Table 1). Cob weight showing the accumulation of water and organic materials contained in the seed. Accumulation of organic material associated with photosynthesis and distribution of photosynthate from the source to the plant organs wich serve as a place for the dumping of photosynthesis products (sink), in this case is corn seed. Similar to cob weight at harvest data, after the cob was air dried, the highest weight value also showed by the Deep Yellow local cultivar and the lowest one was obtained by the Red Blood local cultivar. After air dried for 30 days, cob weight become decreased about 2-6 grams compared with the cob weight at harvest. This was allegedly associated with the reduced of water content in the cobs. The water content in the cob can be decreased along with the length of storage time. This is caused by during storage the evaporation of water can still take place. Drying the cob in an oven lowering the water content in the seed. ${ }^{25}$ When compared with at harvest, and cob weight at air dried, the cob weight after oven dried getting were decreased. Water content is the amount of water contained in the material expressed in percent (\%). ${ }^{26}$ Cob water content at harvest average is $19 \%$. This is not in line with the previous result that stated that the average water content of grains such as sorghum and corn are $20-30 \% .{ }^{27}$ However, the water content is influenced by environmental conditions when harvest and also growth environmental condition. If the harvest was done in the dry season and environmental conditions too dry, then the seed water content can range between $17-20 \%{ }^{2}$ Weight of cobs were measured on a $12 \%$ of water content. This is the balanced or equilibrium condition for the storage of corn grain. ${ }^{28,29}$ The cob length shows that cultivar with the highest cob length was Deep Yellow local cultivar, while the lowest cob length was Red Blood local cultivar. The length of cob size is related to the amount or composition of seed rows on the cob. The amount or composition of seed rows on the cob is closely linked to the success of pollination. In case of drought, little or no viable pollen were produced. If there are slightly fertile or viable pollen that formed, the succes of seed formation will also reduced, and this can affect the position of seed or seed row arrangement on the cob. Cultivars with highest cob diameter was Deep Yellow local cultivar (Table 1). Cob diameter is one of agronomic traits that usually related to the size of seed. Cob diameter also affects the crop yield components. If the seed has length size, the cob diameter tend to larger. Also, the length and diameter of the cob is closely related to the results of a varieties. If the average cob length of one varieties is longger, this varieties are likely to have a higher yield.

Drought occurred in the flowering stage, unviable pollen is potentially to produce and this can leads a lower production, and decrease the number of seeds. ${ }^{30}$ The number of seeds per cob related to the value of anthesis-silking interval because between male and female flowers there must be a synchronization to ensure succesful fertilization, wich in turn affect the formation of seeds. This is in accordance with other fundings that under 
drought conditions, the length time of male and female flower induction, will extend the length of anthesis-silking interval and will affect the corn yield, especilly the number of seeds on the cob. ${ }^{31}$

The results showed that the highest yield of cob at the $12 \%$ of water content was obtained by Deep Yellow local cultivar (0.56 tonnes/ha, and the lowest one in the Red Blood local culti$\operatorname{var}(0.23 \mathrm{ton} / \mathrm{ha})$. In general, the cob yield of all cultivars is very low. This is related to the environmental conditions. Drought that occurred at the flowering stage, is potentially decrease the corn yield, ${ }^{32}$ while if drought was occured during grain filling, this can leads the decrease of corn yields as much as $30-60 \% .^{33}$

The proline content is associated with the yield component of corn. This means that genotype with high proline content tended to be high in the yield components (as found in the Deep Yellow local cultivar). Among six local corn cultivars and reference variety, the highest value of proline content and yield components (except for cob water content after air dry) was showed by Deep Yellow cultivar. Srikandi variety that was recommended by the Research Institute of Cerreal as a drought tolerant variety did not show better result on all variables observed compared with Deep Yellow local cultivar. Another researcher was stated that if a superior variety did not show a high result, ${ }^{34}$ this was caused by the superior variety was gained by some selected optimum procedure and the observation of superior variety was done under optimum condition. Therefore the superiority of this variety under optimum condition does not always expressed under sub optimum condition.

Regarding to the tolerance to drought, it was predicted that Deep Yellow cultivar was the most tolerant cultivar that can adapt to the environment of Kisar Island as it's natural habitat compare with other local cultivar and reference variety. This result was strong supported by statement of, ${ }^{34}$ that if the observed value of one traits from one cultivar were highest than the observed value of one traits from a reference variety (tolerance to drought), the genotype was more tolerant to drought. This suggests that based on the proline content and yield components, the Deep Yellow local corn cultivar are effective to measure the adaptation of corn cultivars, and can be recommended for further cultivation.

\section{Conclusions}

The highest proline content and yield components (except for cob water content) was obtained in Deep Yellow cultivar. The lowest proline content was obtained by Rubby Brown Cob cultivar. The lowest corn yield components (except for cob water content when harvest) was obtained by Red Blood local cultivar. Deep Yellow cultivar can be proposed as superior drought tolerance variety, and can be recommended for further wide cultivation in Maluku province.

\section{References}

1. Safriel U, Adeel Z. Dryland systems. In: Hassan R, Scholes R, Ash N, eds. Ecosystems and human well-being: current state and trends: findings of the condition and trends working group. Washington: Island Press; 2005. pp 623662 .

2. Murtilaksono K, Anwar S. Potency, chalange, and strategy in the use of dryland and acid dryland for agricultural (rice, corn, soybean), veterinary, and using usefull technology and location specific. Proc Natl Sem Suboptimal Land, 2014 Sept 2627, Palembang, Indonesia. pp 1-15. [Article in Indonesian]

3. Susanto AN, Sirappa MP. Future and strategies for corn development in supporting Food availability in Maluku. Res Dev Agric J 2005;24:70-9. [Article in Indonesian].

4. Central Agency of Statistics of South West Maluku Regency. Maluku: Statistic of Southwest Maluku Regency; 2011. [Book in Indonesian].

5. Pesireron M, Senewe RE. Performance of 10 composite corn varieties and hybrid on the dry land agroecosystem in Maluku. J Agric Cult 2011;7:53-8. [Article in Indonesian].

6. Sirappa MP, Pesireron M, Dahamarudin L. Yield potential of some local corn in South West Maluku District with integrated plant management. Proceeding of National Seminars on Cereals, 2013 March 26-27, Banjar Baru, South Kalimantan, Indonesia. pp 220-230. [Article in Indonesian].

7. Mohammadkhari N, Heidari R. Effects of drought stress on soluble proteins in two maize varieties. Turk J Biol 2008;32:23-7

8. Barnaby JY, Kim M, Bauchan G, et al. Drought responses of foliar metabolites in three maize hybrids differing in water stress tolerance. PLoS One 2013;8:24-1

9. Moaveni P. Effect of water deficit stress on some physiological traits of wheat (Triticum aestivum). Agric Sci Res 2011;1:64-4

10. Liu C, Liu Y, Guo K, et al. Effect of drought on pigments, osmotic adjustment, and antioxidant enzymes in six woody plant species in Karst of Southwestern China. Env Exp Bot 2011;71:174-9
11. Rahayu ES, Guhardja E, Ilyas S, Sudarsono. Polyethylene glycol in in-vitro media leading the drought stress to inhibit peanut (Arachis hypogaea L.) shoot. Periodic Biol Res 2005;11:39-7. [Article in Indonesian].

12. Nazarli H, Faraji F. Response of proline, soluble sugars and antioxidant enzymes in wheat (Triticum aestivum L.) to different irrigation regimes in greenhouse condition. Cercetări Agronomice în Moldova XLIV 2011;4:28-5.

13. Tohari S, Shiddieq D. Effect of drought stress on proline accumulation in patchouli (Pogostemon cablin Benth.). Agric Sci 2012;15:85-14. [Article in Indonesian].

14. Effendi R. Response of tolerance and sensitive corn genotype toward drought stress at the germination stage: Proceeding of National Seminar on Cereals, 2009 June 21-26, Jakarta, Indonesia. 2009. pp 82 91.[Article in Indonesian].

15. Efendi R, Suwardi, Isnaini M. Method in determine character for corn genotype selection on drought at the early vegetative phase. Proceeding of National Seminar on Cereals, 2010 July 26-30, Jakarta, Indonesia. 2010. pp 230-240. [Article in Indonesian].

16. Sultan K, Atilla LT. The investigation on accumulation levels of proline and stress parameters of the maize (Zea mays L.) plants under salt and water stress. Act Physiol Plant 2010;32:541-8.

17. Badami K, Amzeri A. Identification of somaclonal varian tolerance to drought on the corn population derived from in-vitro selection using polyethylene glycol. Agrovigor 2011;4:7-6. [Article in Indonesian].

18. Soltani A, Waismoradi A, Heidari M, Rahmati H. Effect of water deficit stress and nitrogen on yield and compatibility metabolites on two medium maturity corn cultivars. Int J Agri Crop Sci 2013;5:737-3.

19. Naghavi MR, Aboughadareh AP, Khalili M. Evaluation of drought tolerance indices for screening some of corn (Zea mays L.) cultivars under environmental conditions. Not Sci Biol 2013;5:388-5.

20. Shaddad MAK, Abd El-Samad MH, Mohammed HT. Interactive effects of drought stress and phytohormones or polyamines on growth and yield of two maize (Zea maize L.) genotypes. Am J of Plant Sci 2011;2:790-17.

21. Bates LS, Walderen RM, Teare ID. Rapid determination of free proline for waterstress studies. Plant Soil 1973;39:205-2.

22. Claussen W. Proline as a measure of stress in tomato plants. Plant Sci 2005;168:241-8.

23. Rachmawati D, Daryono BS, Sukma KPW. Yield potential of hybrid corn, derived from 
the crossing between varietas GulukGuluk variety and Yellow Srikandi-1. Periodic Biol Res Special Edition 2011;5A:153-5. [Article in Indonesian].

24. Mafakheri A, Siosemardeh A, Bahramnejad B, et al. Effect of drought stress on yield, proline and chlorophyll contents in three chickpea cultivars. Aus J Crop Sci 2010;4:580-5.

25. Innocent COA, Gumbe LO Gitau AN. Dewatering and drying characteristics of water hyacinth (Eichhornia Crassipes) petiole. Part II. Drying characteristic. Agric Eng Int 2008;7:11-1.

26. Safrizal R. Material water content. Post harvest technique. Thesisi dissertation. Departement of Agricultural Technique. Faculty of Agriculture Syah Kuala University; 2010. [Article in Indonesian].

27. Susila BA. Excellence quality nutrition and functional properties of Sorghum
(Sorghum vulgare). Proceeding of National Seminar on Inovative Post Harvest for the Industrial Development Based on Agriculture, 2010 Nov 30-Dec 1, Bogor, Indonesia: Center for Post Harvest Research and Development; 2010. pp 1329. [Article in Indonesian].

28. Mwithiga G, Sifuna MM. Effect of moisture content on the physical properties of three varieties of shorgum seeds. J Food Eng 2006;75:486-80.

29. Sedyowati YT. Drying corn is good support achieving sustained self-sufficiency. Ministry of Agriculture. Jakarta: Research Center and Development of Human Resources in Agriculture; 2011. [Article in Indonesian ]

30. Spitko T, Nagy Z, Zsubori ZT, et al. Effect of drought on yield components of maize hybrids (Zea mays L). Maydica 2014;59:161-9.
31. Ali Q, Elahi M, Hussain B, et al. Genetic improvement of maize (Zea mays L.) against drought stress: an overview. Agric Sci Res J 2011;10:228-37.

32. Magorokosho C, Pixley KV, Tonggoona P. Selection for drought tolerance in two tropical maize populations. Afr Crop Sci J 2003;3:151-61.

33. Efendi R, Suwarti. Anticipate climate changes with drought tolerant maize varieties and flooding. Proceeding of National Seminar on Inovation Technology of Agriculture, 2013 March 26-27, Banjar Baru, South Kalimantan: 2013. pp 133-142. [Article in Indonesian].

34. Ceccareli S. Specific adaptation and breeding for marginal condition. Euphytica 1994;77:205-4. 